\title{
Culture supernatants from V. cholerae 01 ElTor strains isolated from different geographic areas induce cell vacuolation and cytotoxicity
}

\author{
Jorge EVidal, PhD, (1) Fernando Enríquez-Rincón, PhD, (2) Silvia Giono-Cerezo, PhD, (3) \\ Rosa María Ribas-Aparicio, PhD, (3) Paula Figueroa-Arredondo, PhD. ${ }^{(4)}$
}

\author{
Vidal JE, Enríquez-Rincón F, Giono-Cerezo S, \\ Ribas-Aparicio RM, Figueroa-Arredondo P. \\ Culture supernatants from V. cholerae OI EITor \\ strains isolated from different geographic \\ areas induce cell vacuolation and cytotoxicity. \\ Salud Publica Mex 2009;5 I:39-47.
}

\begin{abstract}
Objective.To investigate whether the HlyA-induced vacuolating effect is produced by V. cholerae OI ElTor strains isolated from different geographic origins, including Mexico. Material and Methods. Supernatant-induced haemolysis, vacuolating activity and cytotoxicity in Vero cells were recorded. PCR, RFLP analysis and molecular cloning were performed. Results. All ElTor strains analyzed induced cellular vacuolation. Ribotype 2 strains isolates from the U.S. gulf coast yielded the highest titer of vacuolating activity. Eight of nine strains were haemolytic, while all strains were PCR positive for the hlyA gene. We cloned the hlyA gene from two ElTor strains, a toxigenic $\left(25 \mid 4-88, c t x A B^{+}\right)$and a non-toxigenic Mexican strain (CM 91-3, ctxAB-). Supernatant from those recombinant $E$. coli strains induced haemolysis, cell vacuolation and cytotoxicity. RFLP-PCR analysis revealed similarities in the hlyA gene from all strains tested. Conclusion. The HlyA-induced vacuolating effect is a widespread phenotype of epidemic V. cholerae O I ElTor strains.
\end{abstract}

Key words: V. cholerae; haemolysin; HlyA; vacuolating effect
Vidal JE, Enríquez-Rincón F, Giono-Cerezo S, Ribas-Aparicio RM, Figueroa-Arredondo P.

Cepas de V. cholerae OI biotipo EITor aisladas de diferente origen geográfico inducen vacuolización celular y citotoxicidad. Salud Publica Mex 2009;5 I:39-47.

\section{Resumen}

Objetivo. Analizar el efecto vacuolizante de cepas de V. cholerae OI EITor aisladas de diferente origen geográfico, incluyendo México. Material y métodos. Se realizaron pruebas de hemolisis, vacuolización y citotoxicidad en células Vero, así como PCR, análisis por RFLP y clonación molecular. Resultados. Todas las cepas indujeron el efecto vacuolizante. Las cepas del ribotipo 2, aisladas de las costas del Golfo en Estados Unidos, presentaron títulos altos de vacuolización. El gen hlyA fue amplificado en las nueve cepas mediante PCR, aunque sólo ocho fueron hemolíticas. Se clonó el gen hlyA de una cepa toxigénica $\left(25 \mid 4-88, c t x A B^{+}\right)$y de una cepa no toxigénica aislada en México (CM 9I-3, ctxAB). El sobrenadante de las clonas recombinantes indujo hemólisis, efecto vacuolizante y citotoxicidad. El RFLP mostró alta similitud del gen hlyA de las cepas estudiadas. Conclusión. El efecto vacuolizante es un fenotipo ampliamente distribuido en cepas epidémicas de V. cholerae OI biotipo EITor.

Palabras clave: V. cholerae; hemolisina; HlyA; efecto vacuolizante

(I) Department of Microbiology and Molecular Genetics, University of Pittsburgh School of Medicine. Pittsburgh PA, USA

(2) Departamento de Biología Celular, Centro de Investigación y de Estudios Avanzados del Instituto Politécnico Nacional. Mexico.

(3) Departamento de Microbiología, Escuela Nacional de Ciencias Biológicas del Instituto Politécnico Nacional. Mexico.

(4) Programa Institucional de Biomedicina Molecular, Escuela Nacional de Medicina y Homeopatía del Instituto Politécnico Nacional, Mexico.

Received on: February I, 2008 • Accepted on: September 5, 2008

Address reprint requests to: Jorge E.Vidal, PhD. Department of Microbiology and Molecular Genetics, University of Pittsburgh School of Medicine. 200 Lothrop St. Biomedical Science Tower WII I4, University of Pittsburgh School of Medicine, Pittsburgh, PA, I526I, USA.

E-mail: jev20@pitt.edu 
C holera is a diarrheal disease prevalent in the world from ancient times and nowadays it still represents a serious problem in developing countries. The etiological agents, Vibrio cholerae $\mathrm{O} 1$ or $\mathrm{O} 139$, both must produce cholera toxin (CT) which is a potent enterotoxin responsible for lethal symptoms of cholera. Besides CT, other toxins contributing to cholera and cholera-like diseases have been described. For example, zonula occludens toxin (ZOT) and the accessory cholera toxin (ACE), both induce ion absorption alterations and loss of electrolytes through the intestinal epithelium. ${ }^{1}$ V. cholerae heat-stable toxin activates the guanylate cyclase and influxes of $\mathrm{Ca}^{2+}$ ions across the plasma membrane. ${ }^{2}$ The recently described cholix toxin, secreted by non-O1 strains, possesses ADP-ribose transferase activity against ribosomal eukaryotic elongation factor. ${ }^{3}$

$V$. cholerae ElTor haemolysin (HlyA) is another important toxin secreted by most $V$. cholerae $\mathrm{O} 1$ and non-O1 strains. ${ }^{4,5}$ In purified form, HlyA induces enterotoxicity, cytotoxicity, lysis of erythrocytes from several species, and it is lethal for mice. ${ }^{5,6}$ In vivo studies have demonstrated that HlyA is the most important lethal factor of $V$. cholerae $\mathrm{O} 1$ ElTor in a mouse model of intestinal infection. ${ }^{7}$ HlyA also induced fluid accumulation and histopathological damage when a strain of $V$. cholerae non-O1 was injected into rabbit ileal loops. ${ }^{8}$ We recently found that culture supernatants from $V$. cholerae non-O1 strains, isolated from different states of Mexico, induce cellular vacuolation as well as cytotoxicity on HeLa cells. We also demonstrated, using different approaches, that HlyA is responsible for the vacuolating phenotype. We blocked cellular vacuolation by pre-treating the culture supernatant with a neutralizing anti-HlyA antibody. Moreover, culture supernatant from an E. coli encoding the $h l y$ A gene induced cell vacuolation and cytotoxicity. Those non-O1 strains were isolated from patients suffering cholera-like disease in Mexico, strongly suggesting that HlyA was the responsible factor for pathogenesis. ${ }^{9}$

HlyA is secreted as a pro-toxin monomer of $80 \mathrm{kDa}$ which is proteolitically cleavaged to produce the active form of $65 \mathrm{kDa}$. Activated HlyA then binds to the plasma membrane forming a specific anion-selective pentameric channel that leads to cell swelling and lysis., $5,10,11$ It has also been shown that HlyA is internalized and reaches the late endosomal compartment as well as the trans Golgi network. As a consequence, HlyA-formed anionic channels become associated with intracellular compartments characterized by the presence of the v-ATPase. This v-ATPase pumps protons inside the organelles rendering the lumen acidic and forming the cytoplasmic vacuoles. ${ }^{12}$ In addition, recent evidence has suggested that autophagy significantly contributes to the formation of vacuoles. ${ }^{13}$
The HlyA-induced vacuolating phenotype has also been detected using culture supernatant from $V$. cholerae strain isolates from India, Brazil and Argentina., ${ }^{8,14,15}$ Cell-free culture supernatant from $V$. fluvialis strains, which encodes a hlyA-like gene ( $>81 \%$ homology), isolated from patients suffering cholera-like disease, induces cellular vacuolation and cytotoxicity. ${ }^{16}$ This vacuolating effect appears to contribute to the virulence of pathogenic Vibrio species and this can be an important factor contributing to the lethality of epidemic cholera.

The objective of this research work was to investigate whether the vacuolating phenotype is induced by $V$. cholerae O1 ElTor strain isolates from different geographic origins during the seventh cholera pandemic. These ElTor strains have been previously characterized by ribotyping, serotypification and presence of $\mathrm{CT}$ genes $\left(c t x \mathrm{AB}^{+}\right)$by Popivic et al. Ribotypes help to establish the clonality of $V$. cholera $\mathrm{O} 1$ epidemic strains, especially in areas where different ribotypes are present. This study analyzed Latin America epidemic strains belonging to ribotype 5, US gulf coast isolates of ribotype 2. Also used were a ribotype 10 strain from Australia and a ribotype 6 strain from Romania, which is actually the most widely distributed ribotype in the world. ${ }^{17}$ As previously reported, all those reference strains encode ctx $\mathrm{AB}$ genes and secrete CT. ${ }^{17}$ A non-toxigenic V. cholerae O1 ElTor strain (ctx $\left.\mathrm{AB}^{-}\right)$of ribotype 12 was also included, which was isolated in Mexico and characterized by our group and others. 13,17

Our studies showed that all ElTor strains, independently of whether or not they produce $\mathrm{CT}$, induced cell vacuolation and cytotoxicity in Vero cells. This suggests that cell vacuolation is a widespread virulence phenotype of ElTor strains. Those isolates from U.S. gulf coast (ribotype 2) yielded the highest vacuolating titer among all strains analyzed. All other strains yielded low vacuolating titers. We also corroborated that HlyA induces cell vacuolation.

\section{Material and methods}

Bacterial strains. Strains used in this study are listed in Table I. All Vibrio strains were provided by the Cholera Laboratory at Mexico's National Institute of Diagnosis and Epidemiologic Reference (INDRE, which stands for Instituto Nacional de Diagnóstico y Referencia Epidemiológica de México). For DNA cloning, E. coli DH5 $\alpha{ }^{18}$ was used as host. Recombinant $E$. coli strains were grown in Luria-Bertani agar (LB) with $100 \mu \mathrm{g} / \mathrm{ml}$ of ampicillin (Sigma). Experiments shown were performed at the Department of Microbiology of the National School of Biological Sciences, National Polytechnic Institute of 
Mexico (Departamento de Microbiología de la Escuela Nacional de Ciencias Biológicas del IPN ENCB-IPN) and the Department of Cell Biology, Mexico's Center of Research and Advanced Studies (Departamento de Biología Celular del Centro de Investigación y Estudios Avanzados, CINVESTAV).

Cell vacuolation assay and haemolysis test: Vero cells (ATCC CCL-81) were grown in DMEM (Gibco, BRL) and supplemented with heat-inactivated $10 \%$ fetal calf serum (FCS) (Invitrogen), 1\% non-essential amino acids (Sigma), 1\% glutamine (Sigma), penicillin (100 $\mathrm{U} / \mathrm{ml})$, and streptomycin $(100 \mu \mathrm{g} / \mathrm{ml})$. Routinely, cells were treated with $0.25 \%$ trypsin, seeded in flat-bottom 96- well microplates (Falcon) and then incubated at $37{ }^{\circ} \mathrm{C}$ in a humidified $5 \% \mathrm{CO}_{2}$ atmosphere until they reached $70-80 \%$ of confluency.

Vacuolating and cytotoxicity assays: Strains were inoculated in Craig medium [3\% Casaminoacids, $0.4 \%$ Bacto yeast extract, $0.2 \%$ glucose and $0.05 \% \mathrm{~K}_{2} \mathrm{HPO}_{4}$ (pH 7.0)] and incubated at $37^{\circ} \mathrm{C}$ for $16 \mathrm{~h}$ in an orbital rotator (150 RPM). Bacteria were then pelleted and the culture supernatant was filter sterilized through a 0.22 $\mu$ m-diameter filter (Millipore). A $100 \mu \mathrm{l}$-aliquot of sterile culture supernatant was either incubated with cells or serially diluted using DMEM (with $2 \%$ of FCS) and then added to the cell cultures. Treated cells were incubated at $37^{\circ} \mathrm{C}$ for $2 \mathrm{~h}$. The titers of cell vacuolation activity and cytotoxicity were recorded following our previously established criteria. ${ }^{9}$ At the end of the experiment, cells were washed three times with PBS, fixed with methanol (Baker) and Giemsa stained. Pictures were then taken using an upright microscope (Nikon).

To detect haemolysis, strains were inoculated onto blood agar plates (Difco laboratories) containing 5\% rabbit or sheep red blood cells and incubated under conditions described elsewhere. ${ }^{19}$ Haemolysis was scored as positive upon formation of a transparent halo around a single bacterial colony over a period of $48 \mathrm{~h}$. To additionally confirm that the culture supernatant induces haemolysis, we utilized the haemolysis test tube. ${ }^{13}$ In short, $1 \mathrm{ml}$ of a culture supernatant (prepared as mentioned above) was mixed with $1 \mathrm{ml}$ of a $2 \%$ suspension of rabbit or sheep erythrocytes. This suspension was then incubated at room temperature for $1 \mathrm{~h}$ and pelleted by centrifugation. Haemolysis was detected by hemoglobin release into the supernatant at $A_{570 \mathrm{~nm}}$.

PCR procedures: A phenol-chloroform method was used for DNA extraction. ${ }^{20}$ Amplification of hlyA gene from strains was made by using the following primers: Hly Fwd (5'-CTG TCT AGA [XbaI] AGT GAG GTT TAT ATG CCA AAA CTC AAT CGT) and Hly Rev (5'-CTG CTC GAG [XhoI] TTA GTT CAA ATC AAA TTG AAC CCC TTT CAC CAA). ${ }^{9,21}$ The reaction mixture was prepared as follows: $1 \mu \mathrm{l}$ of template DNA $(0.10 \mu \mathrm{g})$, $0.5 \mathrm{U}$ of Taq DNA polymerase (Sigma), $1.5 \mu \mathrm{l}$ of reaction buffer, $2.5 \mathrm{mM}$ of each deoxynucleoside triphosphate, and $10 \mathrm{pmol}$ of each primer. PCR was performed in an automated thermocycler (Perkin-Elmer) for 30 cycles of $94^{\circ} \mathrm{C}$ for $1 \mathrm{~min}, 60^{\circ} \mathrm{C}$ for $1 \mathrm{~min}$, and $72^{\circ} \mathrm{C}$ for $1 \mathrm{~min}$ and a final extension at $72{ }^{\circ} \mathrm{C}$ for $10 \mathrm{~min}$. Reactions were run in a $1 \%$ agarose gel and stained with ethidium bromide for visualization.

RFLP-PCR analysis: Each PCR-amplified hlyA gene was purified by affinity column (Qiagen) and then digested separately with RsaI, HindIII, HincII, BamHI, EcoRI, XbaI, and XhoI (all enzymes from Gibco, BRL) for $3 \mathrm{~h}$ at $37^{\circ} \mathrm{C}$. Reactions were electrophoresed as described above and photographed to analyze the digested fragments. To construct a phenogram, each fragment was scored as binary data. The presence (1) or absence (0) of a determined band was incorporated in a database, and coefficients of similarity were generated by the bandbased method of Jaccard. ${ }^{22}$ A phenogram showing the similarities of the hlyA gene was then generated by the unweighted pair group method with arithmetic mean (UPGMA). Analysis and construction of the phenogram was made using the NTSYSpc2.02j software. Jaccard's index of genetic similarity under 0.5 is considered diverse.

PCR-based cloning of hly A gene: The hlyAgene was PCR-amplified as described above from either 2514-88 or CM91-3 strain. Each PCR product was ligated in PGEMT Easy vector (Promega), transformed into E. coli DH5 $\alpha$ competent cells and then plated in blood agar plates with ampicillin $(100 \mu \mathrm{g} / \mathrm{ml})$. Those recombinant $E$. coli hlyA-clones acquiring the haemolytic phenotype were analyzed by PCR (using primers amplifying the hlyA gene). To further confirm hlyA cloning, the plasmids were digested with $\mathrm{XbaI}$ and $\mathrm{XhoI}$ (restriction enzyme sites were added to both ends of primers) or EcoRI (sites flanking the pGEM-T multiple cloning site).

\section{Results}

Culture supernatant from epidemic strains of $V$. cholerae O1 ElTor induces cytotoxicity and cell vacuolation. It has been previously showed that HlyA-containing culture supernatant from $V$. cholerae $\mathrm{O} 1$ ElTor isolates from India and Brazil induces cell vacuolation. ${ }^{9,14,15} \mathrm{To}$ further evaluate whether $V$. cholerae O1 ElTor strains isolated from different geographic origins can produce cytotoxicity and cell vacuolation, we incubated the culture supernatant from epidemic ElTor isolates with Vero cell cultures for $2 \mathrm{~h}$. As shown in table I, the non-diluted culture supernatant from all ElTor strains induced cytotoxicity in Vero cell cultures. This cyto- 
Table I

StRAINS USED IN THIS STUDY

\begin{tabular}{|c|c|c|c|c|}
\hline \multirow[b]{2}{*}{ Strain } & \multirow[b]{2}{*}{ Description } & \multicolumn{2}{|c|}{ Phenotype } & \multirow[b]{2}{*}{$\begin{array}{l}\text { Reference } \\
\text { or source }\end{array}$} \\
\hline & & Haemolysis & $\begin{array}{l}\text { Cytotoxicity } \\
\text { /Vacuolation* }\end{array}$ & \\
\hline \multicolumn{5}{|c|}{ Vibrio cholerae OI ElTor biotype } \\
\hline $25 \mid 4-88$ & Ribotype 2, US Gulf Coast & + & $+/ 10240$ & INDRE \\
\hline$|064-8|$ & Ribotype 2, US Gulf Coast & + & $+/ 10240$ & INDRE \\
\hline $2164-78$ & Ribotype 2, Louisiana & + & $+/ 10240$ & 17 \\
\hline C7445 & Ribotype 5, Guatemala & + & $+/ 320$ & INDRE \\
\hline C6706 & Ribotype 5, Peru & + & $+/ 80$ & 17 \\
\hline C7986 & Ribotype 5, Guatemala & - & $+/ 40$ & INDRE \\
\hline C7754 & Ribotype 6a, Rumania & + & $+/ 40$ & 17 \\
\hline $2270-77$ & Ribotype 10,Australia & + & $+/ 160$ & 17 \\
\hline CM9I-3 & Ribotype I2, Mexico & + & $+/ 40$ & 13,17 \\
\hline \multicolumn{5}{|c|}{ Vibrio cholerae OI classical biotype } \\
\hline O395 & Epidemic reference strain from India & - & $-/-$ & 19 \\
\hline \multicolumn{5}{|l|}{ Vibrio cholerae non OI } \\
\hline 52201 & Oaxaca, Mexico & + & $+/ 5120$ & 9 \\
\hline 69750 & Tamaulipas, Mexico & + & $+/ 160$ & 9 \\
\hline 44244 & Guerrero, Mexico & + & $+/ 40$ & 9 \\
\hline V. parahaemolyticus WPI & Kanagawa positive strain & + & $+/-$ & 23 \\
\hline E. coli DH5 $\alpha$ & $\mathrm{K}-12$ strain & - & $-1-$ & 18 \\
\hline JEVI8 & E. coli DH5 $\alpha$ derivative encoding pGEMT-hlyA from 25।4-88. & + & $+/ 32$ & This study \\
\hline JEV35 & E. coli DH5 $\alpha$ derivative encoding PGEMT-hlyA from CM 9|-3 & + & $+/ 64$ & This study \\
\hline
\end{tabular}

*The titer of vacuolating activity is expressed as the reciprocal of the highest dilution causing $50 \%$ of cell vacuolation in Vero cells

toxic effect was characterized by rapid appearance of cytoplasmic vacuoles which was preceded by changes on cell morphology, cell contraction, rounding and detachment (figure 1B). A similar cytotoxic phenotype was induced by the culture supernatant from non-O1 $V$. cholerae strains (table I). Cytotoxicity in Vero cells was also induced by haemolysin-containing culture supernatant from $V$. parahaemolyticus, as previously described, ${ }^{23}$ but cytoplasmic vacuoles were absent (figure 1C). In contrast, culture supernatant from a non-hemolytic $V$. cholerae strain $\mathrm{O} 395$ belonging to the classical biotype (which encodes a truncated hlyA gene $)^{24}$ was unable to induce cytotoxicity in Vero cells (figure 1A).

To better characterize the vacuolating phenotype, we incubated a two-fold dilution series of the culture supernatant with Vero cells for two h. As dilutions were incubated, the supernatant-induced cytotoxic effect turned into a striking vacuolating phenotype characterized by the presence of cytoplasmic vacuoles (figure 1D). All $V$. cholerae O1 ElTor strains induced this vacuolating phenotype (table I). Despite being cytotoxic, the diluted culture supernatant from a V. parahaemolyticus strain did not induce cellular vacuolation (data not shown). $V$. cholerae O1 ElTor strain isolates from the US Gulf coast yielded the highest vacuolating titers (up to 10240). All other ElTor isolates yielded low vacuolating titers (ranging from 40 to 320) (table I).

The haemolytic genotype and phenotype of strains using PCR and two haemolysis assays were next confirmed. As shown in table I, the hlyA gene from all strains were PCR-amplified. All V. cholerae O1 ElTor strains but one gave a haemolysis positive reaction. Those results and previous works ${ }^{9,15}$ suggest that cell vacuolation is a widespread phenotype mediated by HlyA-containing culture supernatant from $V$. cholerae strains. 

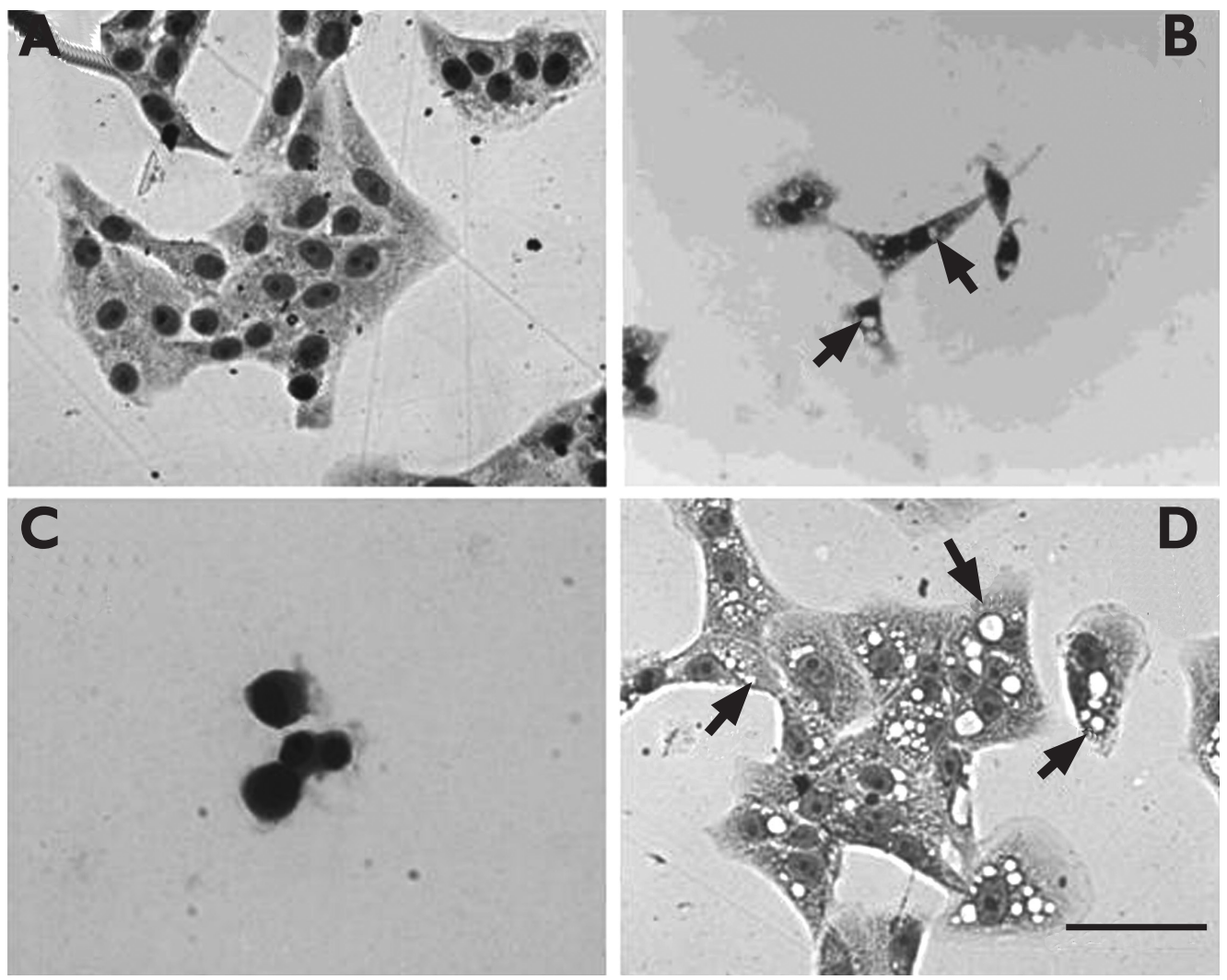

Figure I. Cytotoxicity and Cell vacuolation Caused by culture supernatant from Vibrio cholerae OI ElTor strain 25 I 4-88. V. CHOLERAE OI CLAssical biotype O395 (A), ElTor strain 25 I 4-88 (B), OR V. Parahaemolyticus WI strain (C) WERE GROWN IN CRAIG MEDIUM FOR 18 H, THE CULTURE SUPERNATANT WAS THEN SEPARATED, FILTER STERILIZED AND incubated With Vero Cell cultures for two H. D) Culture Supernatant from ElTor strain 25 I 4-88 Was diluted

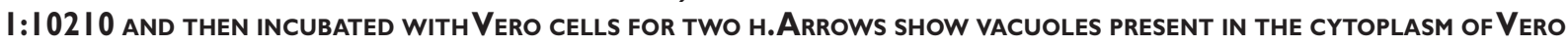
Cells. Cells Were photographed using an inverted microscope. Bar in D = $50 \mu$ is VAlid for all panels

Cloning of the hlyA vacuolating gene: It has been previously shown that $V$. cholerae HlyA can be produced and secreted when the hlyA gene is cloned in E. coli. 9,25 Molecular cloning was used to further corroborate the role of HlyA in cell vacuolation. The hlyA gene was PCR-amplified from chromosomal DNA obtained from V. cholerae 251488 or CM91-3 strain and then ligated into pGEMT plasmid. The plasmid carrying the hlyA gene was then transformed into E. coli DH5 $\alpha$ to obtain the strains JEV18 and JEV35. These recombinant E. coli strains were haemolytic on blood agar plates (table I and figure 2). Plasmids were also extracted and the insert was released using restriction enzymes cutting along the vector or at both ends of the hlyA gene (figure $2 \mathrm{~A}$ ). In addition, culture supernatant from JEV18 and JEV35 in- duced haemolysis and cytotoxicity and cell vacuolation in Vero cell cultures (table I and figure 2). Vacuolating titers of those recombinant strains were low (32 and 64, respectively) (table I). As expected, culture supernatant from $E$. coli $\mathrm{DH} 5 \alpha$ encoding a pGEMT empty vector did not induce haemolysis or cell vacuolation (figure 2B). Results here shown confirm that HlyA secreted by $V$. cholerae ElTor biotype strains isolates from different regions during the seventh pandemic of cholerae induce cellular vacuolation and cytotoxicity.

RFLP analysis of the hlyA gene from epidemic ElTor strains: Since ElTor strains yielded different vacuolating titers, we analyzed the hlyA gene by RFLP. For comparison, three strains of $V$. cholerae non-O1 were also included. Each PCR amplified-hlyA gene 


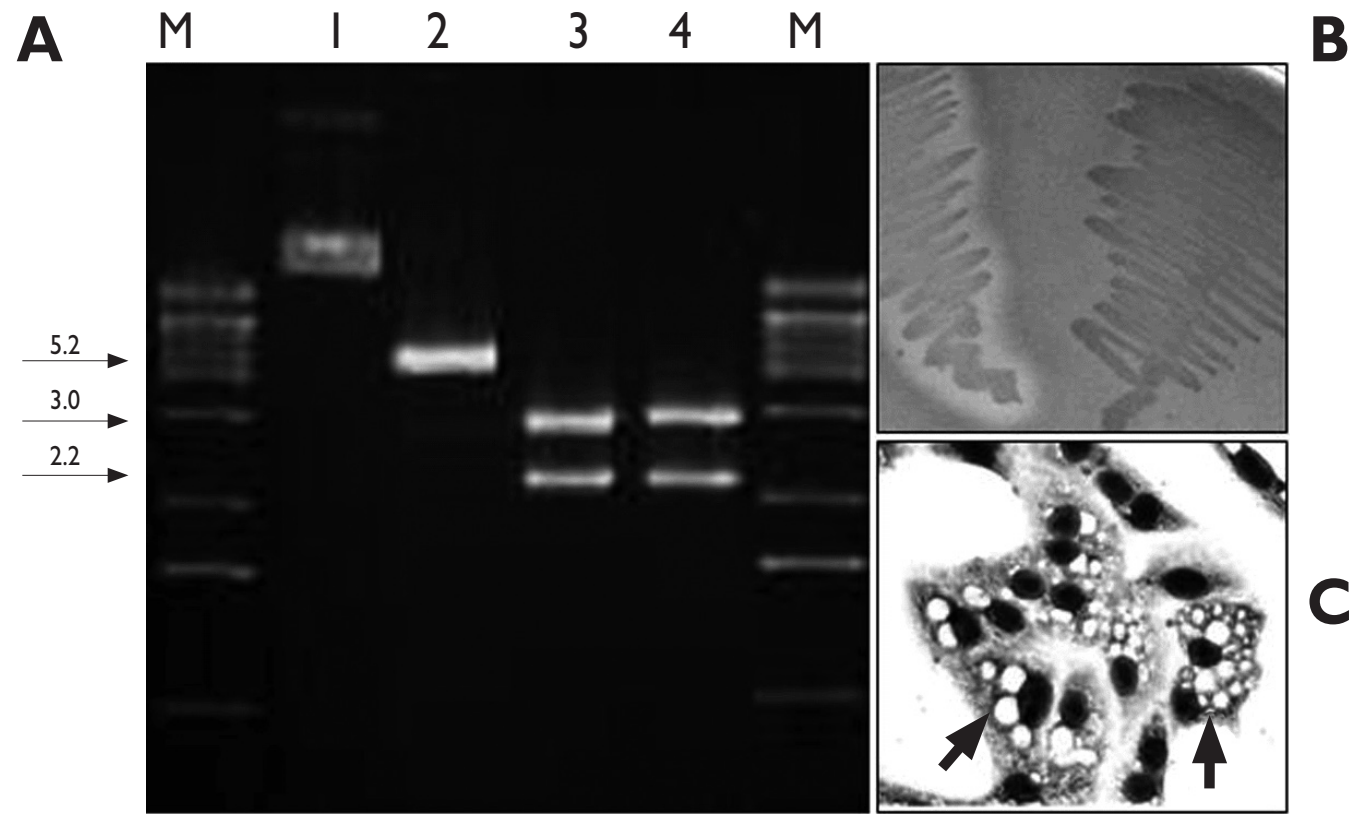

Figure 2. Cloning of the hlyA gene and expression of the vacuolating phenotype. A) Electrophoretic profile of

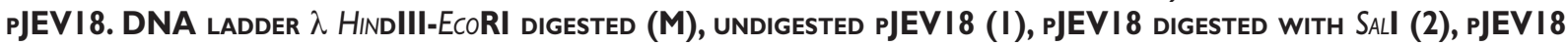
digested With ECoRI (3) and PJEVI 8 digested WITH XBal-Xhol (4). B) HaEmolytic Phenotype. JEVI 8 (LefT) OR E. COLI DH5 $\alpha$ TRANSFORMED WITH A PGEMT EMPTY VECTOR (RIGHT) WAS INOCULATED ONTO BLOOD AGAR PLATES WITH AMPICILLIN and incubated aerobically at $36^{\circ} \mathrm{C}$ for $48 \mathrm{H}$. C). Vacuolating phenotype. Culture supernatant from JeVI 8 Was

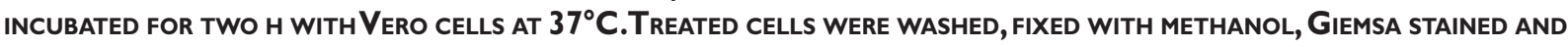
PHOTOGRAPHED.ARroWs PoINT to CYTOPLASMic VACUOLES.

was purified and then digested separately with seven different restriction enzymes named HincII (figure 3A), RsaI (figure 3B), HindIII, BamHI, EcoRI, XbaI and XhoI (data not shown). Those hlyA-RFLP patterns were nearly identical, indicating that the hlyA gene sequence is conserved among epidemic $V$. cholerae O1 ElTor and non-O1 strains. A phenogram depicted using the RFLP's patterns (Material and Methods) showed one major branch including seven strains with $100 \%$ similarity in the hlyA-RFLP pattern. These strains exerted either high or low vacuolating activity (figure 3C). The non-toxigenic $V$. cholerae O1 CM91-3 isolated from Mexico showed a more distant hlyA-RFLP pattern in comparison to all other ElTor strains (figures $3 \mathrm{~A}$ and $\mathrm{B}$ line 9 and $3 \mathrm{C})$.

\section{Discussion}

We described in this research that strains of $V$. cholerae O1 ElTor isolates from different geographic origin during the seventh pandemic of cholera induce cellular vacuolation and cytotoxicity in Vero cells. We also confirmed that HlyA is responsible for these phenotypes. Culture supernatant from two recombinant $E$. coli strains encoding the hlyA gene induced cell vacuolation and cytotoxicity. These results suggest that HlyA could boost the severity of infection in patients infected with toxigenic strains of $V$. cholerae O1 ElTor. Furthermore, it is also likely that the vacuolating factor is responsible for those clinical symptoms of cholera-like disease seen in patients infected with $V$. cholerae O1 CT-negative strains or $V$. cholerae non-O1 strains.

Strains of $V$. cholerae O1 ElTor isolated from US gulf coast induced strong cell-vacuolating activity as measured by the titration assay in Vero cell cultures (table I). Correlating with their cell vacuolating activity, those US gulf coast isolates have been previously described as strongly haemolytic. ${ }^{26}$ Their ability to secrete into the supernatant high amounts of HlyA is still unknown. A putative candidate that up-regulate HlyA secretion is a regulatory protein called HlyU. It was previously shown that HlyU up-regulates hlyA gene expression at 

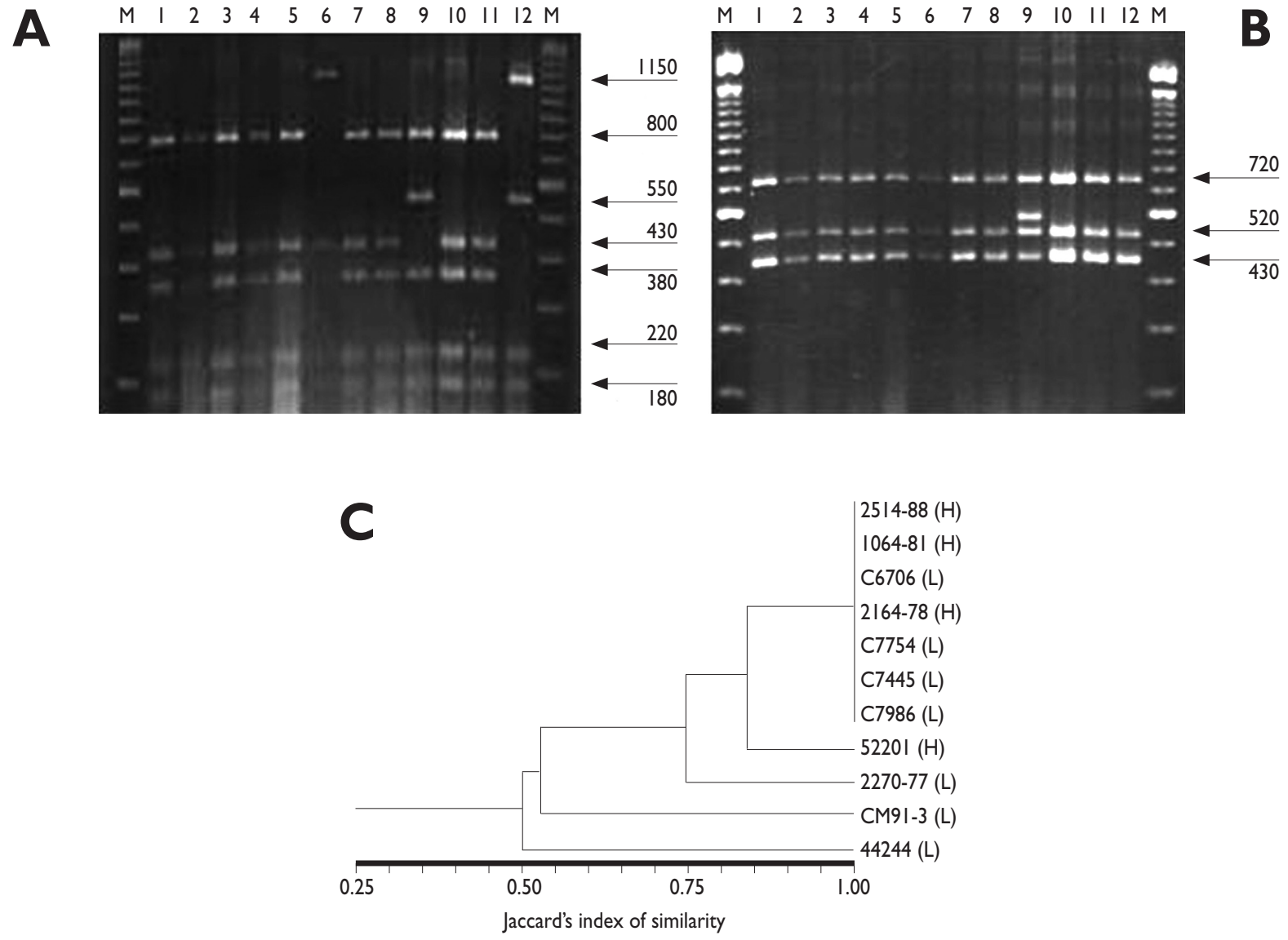

Figure 3. RFLP analysis and phenogram of the hlyA gene. The PCR-Amplified hlyA gene from the corresponding V. Cholerae strain Was digested With A) Hincll or B) Rsal for 3H at $37^{\circ} \mathrm{C}$. Lines (M) I00 BP-LAdDeR, (I) 25 I 4-88, 2) I064-8I, 3) C6706, 4) 2I64-78, 5) C7754, 6) 2270-77, 7) C7445, 8) C7986, 9) CM9I-3, I0) 5220I, II) 69750 AND 12) 44244. Numbers at left indicate base pairs of the corresponding fragment. C) Phenogram derived from the SIMILARITY JACCARD INDEX CALCULATED ON THE PRESENCE OR ABSENCE OF A DETERMINED BAND FROM THE RFLP-PCR ANALYSIS AND CLUSTERED BY THE UPGMA METHOD. A MAJOR GROUP IS IDENTIFIED INCLUDING ELTOR STRAINS WITH EITHER HIGH (H) OR LOW (L) TITER OF VACUOLATING ACTIVITY

the transcription level. ${ }^{27,28}$ Genetic studies are needed to elucidate the role of HlyU in the cell vacuolating activity of those US gulf coast isolates.

The hlyA gene of those isolates used in this study showed genetic similarity. Seven strains had the same RFLP pattern (figure 3). Belonging to this group were strains yielding either low or high vacuolating activity, thereby we could not associate any hlyA RFLP-pattern with the vacuolating activity of strains. Only two ElTor strains (2270-77 and CM91-3) showed polymorphic sites along the hlyA sequence (figure 3). In agreement with our results, Byun et al. found minimum variations along the hlyA gene sequence from different $V$. cholerae isolates, ${ }^{29}$ thus indicating that its genetic sequence is well conserved.

Interestingly, ElTor strain C7986 $\left(h l y \mathrm{~A}^{+}\right)$was unable to induce lysis of erythrocytes, while the supernatant induced cytotoxicity and cell vacuolation (table I). The loss of haemolysis suggests that the vacuolating and haemolytic activities could reside in different domains of HlyA. Rader and Murphy found that the sequence of the hlyA gene from two haemolytic variants of $V$. cholerae ElTor strain RV79 (called $\mathrm{Hly}^{+}$and $\mathrm{Hly}^{-}$) was identical. ${ }^{30}$ Further research is needed to clarify whether HlyA has different domains for inducing haemolysis or cell vacuolation. 
HlyA has been previously linked to clinical symptoms induced by CT negative strains of $V$. cholerae. ${ }^{31}$ Our findings show that the culture supernatant from $V$. cholerae O1 strain CM91-3, which neither produces CT nor encodes $c t x \mathrm{AB}$ genes, induced cellular vacuolation and cytotoxicity. As CM 91-3 strain was isolated from a patient suffering cholera-like disease in Quintana Roo, Mexico and no other known toxin gene but hlyA was detected, ${ }^{13}$ our findings suggest that the gastrointestinal symptoms were mediated by HlyA.

In agree with this hypothesis, it has been recently shown that the supernatant containing an ElTor related haemolysin from clinical isolates of $V$. fluvialis also induces cellular vacuolation. ${ }^{16}$ The HlyA-containing culture supernatant of an Argentinean $V$. cholerae non-O1 strain (CT negative) but not an isogenic hlyA mutant, induces fluid accumulation in rabbit ileal loops and histopathological damage of the intestinal mucosa. ${ }^{8}$

In summary, the present study findings show that $V$. cholerae $\mathrm{O} 1$ ElTor isolates from different geographic origins induce cellular vacuolation and cytotoxicity. It was also demonstrated that these two activities were mediated by HlyA. This property of ElTor haemolysin can give an advantage to strains to potentially increase the clinical symptoms seen in cholera patients.

\section{Acknowledgements}

We thank Dr. Jacobo Zuñiga-Castillo for reviewing the manuscript and his suggestions. This work was generously supported by Mexico's National Council of Science and Technology (CONACyT). JEV is a recipient of a postdoctoral scholarship from CONACyT. The authors thank Dr. G. Rodríguez-Angeles from the cholera laboratory at INDRE for supplying all Vibrio strains.

\section{References}

I. Kaper JB, Morris JG, Jr, Levine MM. Cholera. Clin Microbiol Rev 1995;8(I):48-86.

2. Hoque KM, Pal A, Nair GB, Chattopadhyay S, Chakrabarti MK. Evidence of calcium influx across the plasma membrane depends upon the initial rise of cytosolic calcium with activation of $I P(3)$ in rat enterocytes by heat-stable enterotoxin of Vibrio cholerae non-OI. FEMS Microbiol Lett 200I;196(I):45-50.

3. Jorgensen R, Purdy AE, Fieldhouse RJ, Kimber MS, Bartlett DH, Merrill AR. Cholix toxin, a novel ADP-ribosylating factor from Vibrio cholerae.J Biol Chem 2008;283(I6):1067I-10678.

4. Honda T, Finkelstein RA. Purification and characterization of a hemolysin produced by Vibrio cholerae biotype El Tor: another toxic substance produced by cholera vibrios. Infect Immun 1979;26(3): 1020-1027.
5. Zitzer A, Wassenaar TM,Walev I, Bhakdi S. Potent membranepermeabilizing and cytocidal action of Vibrio cholerae cytolysin on human intestinal cells. Infect Immun 1997;65(4):I293-I 298.

6. Ikigai H,Akatsuka A, Tsujiyama H, Nakae T, Shimamura T. Mechanism of membrane damage by El Tor hemolysin of Vibrio cholerae OI. Infect Immun 1996;64(8):2968-2973

7. Olivier V, Haines GK, 3rd, Tan Y, Satchell KJ. Hemolysin and the multifunctional autoprocessing RTX toxin are virulence factors during intestinal infection of mice with Vibrio cholerae El Tor OI strains. Infect Immun 2007;75(I0):5035-5042.

8. Saka HA, Bidinost C, Sola C, Carranza P, Collino C, Ortiz S, et al. Vibrio cholerae cytolysin is essential for high enterotoxicity and apoptosis induction produced by a cholera toxin gene-negative V. cholerae non-OI, non-OI39 strain. Microb Pathog 2008;44(2): I I8-I 28.

9. Figueroa-Arredondo P, Heuser JE,Akopyants NS, Morisaki JH, GionoCerezo S, Enríquez-Rincón F, et al. Cell vacuolation caused by Vibrio cholerae hemolysin. Infect Immun 2001;69(3):1613-1624.

10. Zitzer A, Zitzer O, Bhakdi S, Palmer M. Oligomerization of Vibrio cholerae cytolysin yields a pentameric pore and has a dual specificity for cholesterol and sphingolipids in the target membrane.J Biol Chem 1999;274(3): I375-1380.

I I. Zitzer A, Palmer M, Weller U,Wassenaar T, Biermann C, TranumJensen J, et al. Mode of primary binding to target membranes and pore formation induced by Vibrio cholerae cytolysin (hemolysin). Eur J Biochem 1997;247(I):209-216.

12. Moschioni M,Tombola F, de Bernard M, et al.The Vibrio cholerae haemolysin anion channel is required for cell vacuolation and death. Cell Microbiol 2002;4(7):397-409.

13. Giono-Cerezo S, Rodriguez-Angeles MG, Gutierrez-Cogco L, Valdespino-Gomez JL. Phenotypic and genotypic characterization of Vibrio cholerae OI. Rev Latinoam Microbiol 1994;36(4):243-25I.

14. Coelho A,Andrade JR,Vicente AC, Dirita VJ. Cytotoxic cell vacuolating activity from Vibrio cholerae hemolysin. Infect Immun 2000;68(3): I700-I705. 15. Mitra R, Figueroa P, Mukhopadhyay AK, Shimada T, Takeda Y, Berg DE, et al. Cell vacuolation, a manifestation of the El tor hemolysin of Vibrio cholerae. Infect Immun 2000;68(4): I928-33.

16. Chakraborty R, Chakraborty S, De K, et al. Cytotoxic and cell vacuolating activity of Vibrio fluvialis isolated from paediatric patients with diarrhoea.J Med Microbiol 2005;54(Pt 8):707-716.

17. Popovic T, Bopp C, Olsvik O,Wachsmuth K. Epidemiologic application of a standardized ribotype scheme for Vibrio cholerae OI.J Clin Microbiol 1993;3 |(9):2474-2482.

18. Hanahan D, Meselson M. Plasmid screening at high colony density. Methods Enzymol 1983;100:333-342.

19. Richardson K, Michalski J, Kaper JB. Hemolysin production and cloning of two hemolysin determinants from classical Vibrio cholerae. Infect Immun 1986;54(2):415-420.

20. Sambrook J, Fritsch EF, Maniatis T. Molecular cloning : a laboratory manual. 2nd ed. Cold Spring Harbor, NY: Cold Spring Harbor Laboratory, 1989.

2I. Mitra RK, Nandy RK, Ramamurthy T, Bhattacharya SK, Yamasaki S, Shimada T, et al. Molecular characterisation of rough variants of Vibrio cholerae isolated from hospitalised patients with diarrhoea.J Med Microbiol 200I;50(3):268-276.

22. Boldo XM,Villa-Tanaca L, Zuniga G, Hernandez-Rodriguez C. Genetic diversity among clinical isolates of Candida glabrata analyzed by randomly amplified polymorphic DNA and multilocus enzyme electrophoresis analyses.J Clin Microbiol 2003;4I(10):4799-4804.

23. Nishibuchi M, Kaper JB.Thermostable direct hemolysin gene of Vibrio parahaemolyticus: a virulence gene acquired by a marine bacterium. Infect Immun 1995;63(6):2093-2099.

24.Alm RA, Manning PA. Biotype-specific probe for Vibrio cholerae serogroup OI.J Clin Microbiol 1990;28(4):823-824. 
25. Alm RA, Manning PA. Characterization of the hlyB gene and its role in the production of the El Tor haemolysin of Vibrio cholerae OI. Mol Microbiol 1990;4(3):413-425.

26. Barrett T], Blake PA. Epidemiological usefulness of changes in hemolytic activity of Vibrio cholerae biotype El Tor during the seventh pandemic. J Clin Microbiol 198I;I3(I):I26-I29.

27.Williams SG, Manning PA. Transcription of the Vibrio cholerae haemolysin gene, hlyA, and cloning of a positive regulatory locus, hlyU. Mol Microbiol I99|;5(8):203I-2038.

28. Williams SG,Attridge SR, Manning PA. The transcriptional activator $\mathrm{Hly} \mathrm{U}$ of Vibrio cholerae: nucleotide sequence and role in virulence gene expression. Mol Microbiol 1993;9(4):75I-760.
29. Byun R, Elbourne LD, Lan R, Reeves PR. Evolutionary relationships of pathogenic clones of Vibrio cholerae by sequence analysis of four housekeeping genes. Infect Immun 1999;67(3): I I |6- I I 24.

30. Rader AE, Murphy JR. Nucleotide sequences and comparison of the hemolysin determinants of Vibrio cholerae El Tor RV79(Hly+) and RV79(Hly-) and classical 569B(Hly-). Infect Immun 1988;56(6): I4I4-I4I9. 31. Ichinose Y,Yamamoto K, Nakasone N, Tanabe MJ, Takeda T, Miwatani T, et al. Enterotoxicity of El Tor-like hemolysin of non-OI Vibrio cholerae. Infect Immun 1987;55(5):1090-1093. 